\title{
Engage or Entertain? The Nature of Teacher/Participant Collaboration in Process Drama for Additional Language Teaching
}

\author{
Erika Piazzoli
}

\begin{abstract}
This paper was presented at the conference 'Plot me no plots: Theatre for University Language teaching' held at the University of Padua in October 2011. The presentation included a practical demonstration of the teacher-in-role strategy and a discussion. Process drama is an experiential approach that has been gaining momentum in the field of language teaching; it is a genre of applied theatre in which the participants, together with the facilitator, engage in the co-construction of a story. As an improvised dramatic form, it encourages negotiation of meaning through the process of experience and reflection. In this article, I reflect on the nature of the collaborative process between teacher and participants in process drama, drawing on my doctoral research on the aesthetics of process drama for teaching additional languages. In this research, I worked with three cohorts of adult language learners, studying Italian as a Second Language (L2), and three cohorts of teachers of Italian (L2) new to drama. I draw on classroom data to illustrate two of the main dramatic strategies of the form: 'teacher-in-role' and 'mantle of the expert'. I introduce these strategies, situate them in a theoretical context and discuss issues and implications when teaching to engage, rather than to entertain.
\end{abstract}

\section{Introduction}

Process drama is a genre of applied theatre in which participants, together with the facilitator, engage in the co-construction of a dramatic world (Bowell and Heap 2001). The origins of process drama date back to the 1970s, when educators Bolton and Heathcote started to practice and reflect on what was then referred to as 'drama in education' (Bolton 1979). Educational drama as an experiential pedagogy was used to teach history, drama and English (L1) in a variety of educational settings, mainly primary and secondary contexts. In the 1990s, Cecily O'Neill laid the structural foundations for the pedagogy (O'Neill 1995). O'Neill describes process drama as a thematic exploration, rather than 
isolated skits, where the outcome is not predetermined, but discovered in process. Process drama proceeds without a script, does not culminate in a final performance, and is characterised by the absence of any external audience. All participants (including the teacher) take on different roles and become involved in the creation of a story, experiencing a dramatic context for educational purposes.

In the field of Additional Language (AL) teaching, in the last two decades process drama has gradually gained recognition as a valid approach (Stinson and Winston 2011). The first step towards an integrated AL process drama approach took place in 1998, with the pioneering work of O'Neill and Kao (1998). The researchers conducted an empirical study at the University of Taiwan, with a group of learners of English as a Foreign Language (EFL); they described process drama as a 'liberating approach', consistent with communicative principles of language teaching. Since then, process drama has been used in various contexts to facilitate language learning, with some promising results. For example, Stinson $(2008 ; 2006)$ experimented using process drama with EFL learners in Singapore; Araki Metcalfe worked with English learners in Japan (2001) and Japanese learners in Australia (2007); I conducted some research with adult learners of Italian (Piazzoli 2010); while Rothwell (2011) specialized in process drama and assessment in the teaching of German. Other quantitative and qualitative data suggest that drama can be beneficial to stimulate fluency in the target language, increase motivation (Belliveau et al. 2007), and make meaning (Yaman Ntelioglu 2011).

These encouraging results generated a desire to fund specialized teacher training programs, which could help AL teachers to assimilate the approach. Indeed, as Schewe (2002) has argued, language pedagogy can benefit considerably from drama in education. However, recent studies have unveiled a degree of resistance in some AL teachers, new to process drama, when implementing the approach in the classroom. Despite admitting it was a helpful tool to promote language learning, two cohorts of teachers from two independent studies manifested resistance (Araki Metcalfe 2008; Stinson 2009) in using process drama independently in the classroom. I believe this apparent contradiction might stem from trying to adopt an instrumental stance, when working with an aesthetic mode. In effect, when learning process drama, teachers are not just learning a new method; they are apprehending a dramatic form. Attempting to use process drama in an instrumental way, without attention to the artistry, can be a sterile, fruitless gamble (Dunn and Stinson 2011).

A characteristic of process drama is that the teacher often takes on a role within the drama, actively engaging in the improvisation with co-participants. This strategy, referred to as 'teacher-in-role', is particularly beneficial for L2/AL learners; indeed, it has been described as "one of the most effective ways to begin a process drama" (Kao and O'Neill 1998: 26). However, playing a dramatic role can be a daunting task for an unexperienced teacher; its purpose can easily be misinterpreted, either by the teacher or by the participants and, 
if misunderstood, it can be counter-productive for the learning environment. In this paper I analyse these dynamics, focussing on one specific issue: the function of engaging learners, as opposed to entertaining them, in the language classroom. I analyze the nature of teacher/learners interaction during the improvisational process, situating my argument in relation to educational literature and offering examples from my reflective practice.

I draw on data from a research project on the aesthetics of process drama for additional language learning, involving three cohorts of adult learners of Italian as a Second Language (L2), and three cohorts of teachers of Italian (L2). Each cohort participated in fifteen hours of process drama, either as active participant (student-participants), or participant-observer (teacher-participants). All the dramas were digitally-recorded for research purposes. The data collection took place in mid-2010 in three language teaching institutions (a university and two private schools) in Milan, Italy. I used multiple case studies, framed by reflective practitioner methodology (Schön 1983), to observe and explore the kind of engagement generated by L2/AL process drama. Through phenomenological lens, I focused on learners' communicative, intercultural, and affective engagement, and how these can influence dramatic and aesthetic engagement. In this paper, I draw on one of the three case studies, analyzing transcripts of classroom interaction, students and teachers' interviews, and questionnaires, to reflect on the nature of the teacher/student collaboration in the L2 drama classroom.

\section{Process Drama: Structure and Strategies}

Although process drama depends on improvisation for its content, it relies on a set framework for its structure. The support of a teaching structure in the planning is crucial for the smooth functioning of the improvisation. To begin with, a process drama always starts with a 'pre-text' (O'Neill 1995), an initial stimulus which launches the dramatic world. The pre-text can be an image, a newspaper article, a song, a short film or other item; any stimulus which triggers curiosity and motivation. This is similar to the communicative language class, where the L2/AL teacher may begin the class with an initial input to brainstorm, elicit vocabulary and introduce the main theme. In process drama the pre-text also provides the initial input, but goes beyond that; it becomes an ongoing thread for the entire duration of the drama. It constitutes the platform on which to create the roles and situation of the dramatic world; it contains the implicit tension which will fuel the dramatic explorations; it evokes unanswered questions that can create a particular mood or dramatic focus. After launching the pre-text, the process drama structure can be divided into three phases: the initiation phase, where participants create their own roles and become immersed in the dramatic situation; the experiential phase, where participants explore the dramatic world through several strategies, or 'conventions'; and a reflective phase, where participants reflect on the learning, making their own meanings explicit (O'Toole and Dunn 2002). Within each 
phase, the participants experience a number of scenarios, or 'episodes'. These episodes are not inter-connected in a linear, chronological sequence, but follow a non-linear narrative, playing with spatial and temporal dimensions in order to explore a theme, within the realm of human emotions and behaviour.

For the purpose of this paper, I focus on the experiential phase, the central phase of the process drama teaching structure. During the experiential phase, the facilitator makes use of dramatic strategies, or conventions, to structure the experience. Currently there exist over eighty process drama strategies, documented elsewhere (Bowell and heap 2001; Neelands and Goode 2000); each convention has a different purpose and can be used by the educator to create empathy, or distance, with respect to a certain theme or dramatic situation. An experienced drama educator will have assimilated most of these conventions and will intuitively know when to use one, rather than another, in the course of the experiential phase, following the participants' responses to the drama. In particular, amongst all conventions, two strategies underpin the core of the experiential phase: 'teacher-in-role' and 'mantle of the expert' (Heathcote and Bolton 1995). These strategies, often misunderstood by teachers new to process drama, are crucial for a smooth functioning of the drama; hence it is important here to clarify their function.

The 'teacher-in-role' strategy was created by Heathcote (1973); it involves the teacher taking on a role within the drama and improvising alongside the participants. It is an innovative pedagogical strategy which involves a number of changes to traditional classroom patterns of interaction. Firstly, teacher-in-role involves a status change: it reverses the Teacher/Students (T/STS) hierarchy of the traditional, teacher-centred approach, where the teacher may ask rhetorical questions to the students, encouraged to respond only when called upon. This requires the teacher to become aware that she/he is enacting a social role as 'teacher' in the classroom-environment, to consciously step out of this role, and take on a different role. Through teacher-in-role, the facilitator can choose to have a lower status than the participants, setting up a more interesting dynamic in terms of agency, power and control. Secondly, 'teacher-in-role' involves a language register change: in line with the status and of the new role, the language undertaken by the teacher will necessarily change. This exposes participants to 'authentic' registers of communication (Van Lier, 1996). In doing so, it opens up to other socio-linguistic contexts, normally not practiced in routine L2/AL classroom dynamics. As a result, 'teacher-in-role' creates a change of interaction dynamics; it engages participants in dialogic communication, in line with sociocultural principles of language learning (Lantolf, 2000).

Similarly, 'Mantle of the Expert' also reverses the T/STS hierarchy of traditional classroom interaction. This pedagogical strategy was also created by Heathcote, in collaboration with Bolton (1995), and it is often presented in parallel with teacher-in-role. As has been argued, it is now recognised as a major vehicle to teach the curriculum in a highly creative and meaningful manner (Winston 2011). In 'Mantle of the Expert', students take on the role of experts to carry out a task and/or to solve a mystery within the drama. 
Students might become expert scientists, journalists, or anthropologists who are commissioned to carry out a project within the drama, in order to shed light on an ambiguous situation. For example, in my practical demonstration at the 'Plot me no plots: Theatre for University language teaching' conference in Padova (2011), I asked the conference delegates to take on the role of BBC journalists, who were short of work and were desperate for any story in order to keep in the business (video clip 1). I took on the role of a homeless man, who had once been a scientist in the Neutrino OPERA team experimenting on light particles. The journalists, who had prepared some questions for the scientist, were unaware of his current homeless state. Indeed, the function of teacher-in-role is to challenge stereotypes, to generate tension and provoke a reaction. The journalists were expecting to meet a successful scientist; they found an outcast, preoccupied with mathematical riddles, sitting on cardboard boxes. When they met him, they had to interact and respond, in role, quickly adapting to this new situation. Using 'Mantle of the Expert', the power dynamics were reversed: due to their higher status, the journalists had the agency to offer the homeless scientist a chance to share the story that brought him to misery. The homeless man was initially suspicious, but would gradually become persuaded to share his story with the journalists. In that instance, I combined teacher-in-role (taking on the role of the homeless) and mantle of the expert (enroling participants as journalists) to demonstrate the beginning of a process drama workshop, which could have led to investigating what happened in the Neutrino experiment team, writing a story for the BBC, preparing a current affairs on the story, and so forth, according to the group's imagination. In terms of its application to L2/AL teaching and learning, 'mantle of the expert' is particularly helpful, as it can boost confidence levels, lowering the speakers' affective filter, increasing willingness to communicate spontaneously, and decreasing language anxiety (Piazzoli 2011) therefore creating an environment conducive to Second Language Acquisition (SLA).

'Teacher-in-role' and 'Mantle of the Expert' function as strategies for learning, as well as significant principles of teaching (Kao and O'Neill 1998). Both strategies are grounded in constructivist theories of learning, according to which knowledge is not passively poured into students' heads, but it is actively constructed by each learner. They are based on the idea of 'cognition' not as an item located within the individual thinker, but a process distributed across the knower, the environment in which knowing occurs, and the activity in which the learner participates (Barab and Squire 2004). They align with Vygotsky's (1978) concept of learners Zone of Proximal Development (ZPD), which holds that when learners participate in spontaneous, symbolic play, taking on the personae of others, they can reach a developmental level above their actual level. Process drama resonates with this notion, as it considers 'playing' as highly beneficial for the learning process. It endorses Bruner's argument (1976) of 'play' as a behaviour that minimises the consequences of one's actions, providing opportunities to try out combinations of new behaviours without anxiety or external pressure for success. The constructivist framework also aligns with AL 
learning theories, as adult language learners operate within the learners' ZPD when learning a language (Platt and Brooks 2002). Through teacher-in-role and mantle of the expert, AL process drama teachers can work within the ZPD to model language and provide a level of scaffolding. During the experiential phase, learners are empowered and exposed to authentic registers of verbal and non-verbal communication; during the reflective phase, the teacher can guide learners to reflect and analyse the language arising in the improvisation.

The teacher taking on a role resonates with Eisner's (1985) discourse on 'teaching as an art'. Eisner argues that teaching is an art guided by educational values, personal needs and beliefs held by the teacher. Echoing Dewey (1934), Eisner defines 'art' as a process in which skills are employed to discover ends through action, as opposed to 'craft' where skills are employed to arrive at preconceived ends. He advocates that artistry in teaching is important because the teacher who functions artistically provides learners with sources of aesthetic experiences that can foster exploration, risk-taking and disposition to play (1985: 183). Of course, Eisner's principles of teaching as an art can be applied to the teaching of any disciplines; specifically, in the teaching of AL through process drama, Eisner's paradigm becomes even more significant as risk-taking, exploration and play are the essence of improvisation, the vehicle through which the language teaching/learning occurs.

\title{
3 Teacher-artist or Teacher-entertainer?
}

In both 'teacher-in-role' and 'mantle of the expert', the teacher's aim is not acting, nor entertaining, but engaging participants through the art of improvisation. As Kao and O'Neill point out:

\begin{abstract}
The initial purpose of taking on a role is emphatically not to give a display of acting, but to invite students to enter and begin to create the fictional world. When the teacher takes on a role in the interaction, it is an act of conscious self-presentation, and one that invites the students to respond actively, to join in and to extend, oppose or transform what is happening (1998: 26)
\end{abstract}

O'Neill (2006) calls the process drama teacher a 'teacher-artist', working alongside the learners in a process of dramatic exploration. She argues that, in process drama, the teacher is likely to function most effectively from within the creative process, as 'co-artist' with his/her participants, rather than remaining on the outside of the work (2006: 51). The relationship between artist and co-artists in process drama is a complex one. The teacher simultaneously covers four functions: playwright, director, actor and educator; the participants function as playwrights, directors, actors and learners. Both teachers and participants concurrently engage in all four functions, negotiating a dynamic spiral of creative exchange (Bowell and Heap 2005). However, as O'Neill reiterates (2006), the 'actor function' of teacher-in-role is not to be understood as a display of acting: the teacher working in role engages in an 'act of conscious 
self-presentation' that invites the students to respond actively. In O'Neill's words, "Students are challenged to make sense of what they see, to become aware of their own responses, and to use these responses as impetus for action" (2006: 109).

In this sense, it is clear how the process drama teacher is operating as an artist. However, in 'Structure and Spontaneity', O'Neill (2006) points out the subtle, but fundamental difference between the teacher as artist, and the teacher as entertainer: the teacher-artist involves the students as active co-artists; the teacher-entertainer involves the students as passive audience. The extract below is a transcript ${ }^{1}$ of an 'unsuccessful' teacher-in-role intervention, where my participants, with no experience in process drama and little willingness to collaborate, did not engage in the artistic exploration. This was part of a one-off process drama demonstration to recruit potential participants for my case study intervention. I was in role as Mario, a lonely Customs Officer, working in the International Airport of Milan:

1. (Teacher [TiR], in role as Mario, arrives and sits on a chair)

2. (6 second silence)

3. TiR: Well?

4. S1: Can we ask questions?

5. TiR: What questions?

6. (A mobile phone rings)

7. TiR (agitated): Who is it? Who's there? Who is it? Is it someone who forgot their passport?

\section{8. (Giggles)}

9. TiR (excited): Who is it? Is it for me?

10. (Giggles. 5 seconds silence)

11. TiR (miserable): Well... it's never for me. That's the problem.

\footnotetext{
1 These transcripts have been translated from Italian (L2) into English. Translating data is a complex issue when dealing with qualitative research reports. As Marshall and Rossman point out (2006), a number of considerations need to be addressed: 1 . acknowledging that the data has been translated, 2. acknowledging whether the translator is the researcher or someone external, and 3. Whereas the translator was involved in the analysis. In this research project, the data was translated into English by the primary researcher; the translations were further checked for accuracy by an associate researcher, who is a NAATI accredited translator (National Accreditation Authority for Translators and Interpreters) from Italian into English. As the originals are utterances by speakers of an Additional Language, the English translation has attempted to reproduce, where necessary, the presence of grammar mistakes.
} 
12. (An SMS notification alert from the same phone)

13. TiR (turns to the mobile phone owner): Is it for me?

14. (Laughter)

15. S2: No, it's for me.

16. TiR (disappointed): It's for her. Is it for you, Miss, are You sure?

17. S2: Yes, I'm sure.

18. (5 seconds silence)

[2.1.2: 30:52] In this instance, the participants are not actively interacting, except for the one student directly involved. In the transcript, one can note the lack of collaboration, the gaps of silence and the nervous giggling. Visual cues from the video recording data are also significant in terms of body language: I lean forward towards the participants, while they remain stiff. As the phone rings, I, in my role as Mario, incorporate this event into the drama, improvising a response; the participant directly involved responds sharply, without playing along in the drama. There is a mismatch in expectations, and the situation becomes stagnant. After this 50-second interaction, my efforts painfully continue for another seven minutes and, gradually, I captured their attention. However, most participants did not feel the need to collaborate; they were framing me as an 'entertainer', passively gazing as I 'performed' a role.

O'Neill (2006) warns that the notion of teacher as 'performer' can be misleading; drawing on McLaren (1986), she argues that the 'teacher-asentertainer' is not the function of teacher-in-role. "The teacher-as-entertainer may engage the students", O'Neill argues, "but they remain a passive audience of isolated and un-reflective spectators. When students remain isolated viewers of the action, they are being entertained" (2006: 108). The entertainer, she argues, is not the most effective model for the teacher, as it won't generate an active response. On the contrary, the teacher-artist generates an active, improvised response.

Improvisation as an art is based on the principle of 'accepting', rather than 'blocking' other players (Johnstone 1999), actively listening and responding, rather than 'cutting off', or using pre-conceived ideas. These basic principles of improvisation are the foundation for any improviser, and underpin the core attitude of 'teacher-in-role' strategy. However, from the episode above I realized that it is not enough for these attitudes to be implicit in the teacher' system of beliefs; they also need to be made explicit to, and shared by the participants. When working with any students, and especially with non-drama students, it is essential that the teacher discusses these values in the first class, as a premise for the work to follow. Owens and Barber refer to this agreement as 'the drama contract', "when a practitioner and a group enter into an agreement to do something on mutually agreed binding terms" (2005: 5). By openly 
discussing these principles, the teacher helps participants to feel "ownership of their drama" (2005: 7) so that the artist/co-artist collaboration can be more balanced. In other words, for process drama to be a truly artistic collaboration, teacher and students' attitudes need to align in the language/drama classroom. If that does not occur, students might frame the teacher as 'the entertainer' in spite of her own implicit beliefs of functioning as a 'teacher-artist'. In the next section, I provide an example of a different type of interaction, a 'teacher-artist' collaboration.

\section{Teacher-artist: A Case Study}

The case study described below took place in a private school of Italian as Second Language in Milan, Italy, where I designed and facilitated a 15-hour process drama, mixing different research methods. For this case study, I worked with a group of eight adult learners of Italian (the brave ones who returned after the one-off session described above) at an intermediate level of proficiency, and a group of four teachers of Italian (L2). The teacher-participants in this case study had extensive experience in L2 teaching, but had no experience in drama. They took observational notes, and participated in individual interviews before and after the class. They also participated in a focus group at the end of the drama intervention, where I used the Video-Stimulated Recall (VSR) research strategy to generate discussion. This technique consists in showing teachers video extracts of classroom practice and getting them to comment or free-associate. VSR has been used extensively in educational research to prompt participants' cognitive mechanisms, to gain insight into implicit theories and beliefs and into relationships between beliefs and actions (Ethell and McMeniman 2000). Student-participants were interviewed individually and in a focus group, where I used a kinaesthetic method of interviewing, based on the props from the drama, as a trigger to stimulate discussion. Student-participants also completed a set of five questionnaires (one at the end of each workshop) self-evaluating their engagement levels with one specific moment of the drama (of their preference). The questionnaire was based on three parameters: communicative, intercultural and affective engagement, using a scale from 0 (not engaged at all) to 10 (highly engaged). The questionnaires were written using simplified language, in line with participants' needs as non-native speakers. As a teacher-researcher, I kept a reflective journal with my phenomenological observations. I used NVIVO 9.1 software for managing, coding and cross-referencing all data sets.

The drama intervention was structured as a series of five 3-hour workshops; in this particular case study, the course was offered by the School as an intensive one-week program. The pre-text I used to design this process drama is the award-winning short film Buongiorno, a five-minute piece produced by BekaFilms (2005) and directed by Melo Prino ${ }^{2}$. In the film, a middle aged man

\footnotetext{
${ }^{2}$ Material used with permission of producer BekaFilms and director Melo Prino.
} 
wakes up in the morning to discover that his own reflection in the mirror is alive. The protagonist goes back to sleep, and the viewers are led to believe that those images were nothing but a nightmare; however, a daunting twist reveals this to be his real-life condition, featuring a grotesque 'nightmare-within-thenightmare' sequence which will ultimately terrify him. The film is silent, except for one word uttered by the mirror reflection: 'Buongiorno!' ('Good Morning'). The soundtrack of the film, by composer Ennio Morricone, is more eloquent than any dialogue to create a mood of suspense, trepidation and angst.

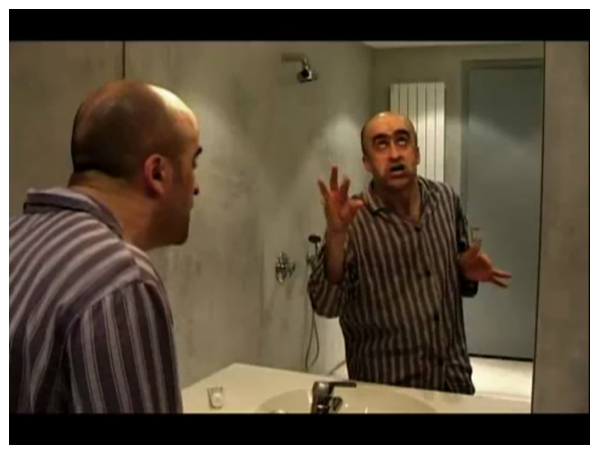

Figure 1: A frame from the short film 'Buongiorno', used as a pre-text for the process drama.

After viewing and discussing the pre-text, I enrolled the participants as 'psychologists', who had been commissioned to help the protagonist of the film. As a group, we decided on a name for the protagonist, his age and personality. The only detail I provided was his profession: he worked as a teacher of Italian as a Second Language and, that day, he had not gone to class. In role as the director of the psychologists, I told the team that after experiencing the mirror delusions, the man had developed a mental block and refused to speak; he had frozen inside the lift of his apartment block. The participants/psychologists had to devise a rescue plan for the man, guided by myself in role as the team director. A complete account of this process drama is beyond the scope of this paper; the learning structure and strategies have been thoroughly documented elsewhere (Piazzoli 2011b).

For the purpose of this paper, I will focus on the function of 'Teacher-in-Role' and 'Mantle of the Expert' and on its implications on participants' engagement. To begin with, I used the teacher-in-role strategy taking on the role of the director of the psychologists. This role was not an overtly low-status role, like, for instance, the homeless scientist in the example above. My choice in taking the role of 'the team director' was dictated by the fact that the cohort of students had never done any drama before; as their first drama, they needed to be guided in the process. However, there are many ways of manipulating role and status; one is through the attitudes of the role. I chose to play the role of a disorganised, hopeless, anxious leader, constantly needing the validation of the team members for reassurance. Through the attitudes of my role, I embodied a status lower than my team members', heavily relying on their expertise. 
Both teacher-in-role and mantle of the expert worked together to empower the learners, reversing the classroom status dynamic. Below is an extract from the transcript of the first teacher-in-role episode (video clip A) ${ }^{3}$ :

1. TiR (anxious): if that's OK with you, I'll give you this task (panicked) don't touch!

2. (Hiro, Yoriko and Sandra laugh)

3. TiR: I'll give you this task, I assign you this task; you have three days... to convince this... fellow... (turns around to read patient's name) 'Ferro'... to talk... or to try to analyse what's happ-

4. Yoriko (provocative): -Excuse me, but I... have to make my dog go for walks, I don't have time (uninterested, confident face). For me ... my dog is more interesting (sarcastic smile).

5. TiR: Of course! You find your dog more interesting! Perhaps we could do a case study on $\mathrm{You}^{4}$ ?

6. (Olga and Sandra laugh)

7. Yoriko: No!

8. TiR: At this stage -

9. Yoriko: No, no, I don't want to, the dog is mine!

10. TiR: But how will you feed Your dog, if next year you'll find Yourself without a job?

11. Yoriko: No, I keep job...

12. (Hiro laughs)

[2.2.3, 26:30] One can note how, in Turn 4, Yoriko openly interrupts and challenges the teacher-in-role, subverting the traditional pattern of classroom communication. Also note my improvisation (Turn 5), in response to her provocation and the negotiation of meaning that follows. At first, it is likely that Yoriko does not understand my comment as she replies "The dog is mine" (Turn 9); however, through the course of the improvised interaction, we are able to negotiate the meaning without interrupting the flow. In my journal, I comment:

Through this interaction, Yoriko implies a willingness to be playful, confronting. She is not scared of challenging my high status in the drama (CS2 RJ, p.16: 53-55).

\footnotetext{
${ }^{3}$ All participants signed an informed consent, agreeing to be in this video; all names in the transcripts are pseudonyms.

${ }^{4}$ Capital Y denotes use of formal register in Italian (Lei).
} 
Later in the same episode, another participant unexpectedly interrupts me. As I am about to leave the space, I get up, walk to the end of the space to shake a psychologist's hand. A commotion arises out of this gesture (hand-shake), and its significance in terms of power and status. From my perspective as teacher-artist improvising, I had not planned for the hand-shake at all; it was a spontaneous gesture, done as a closure to the end of the meeting. I randomly picked Catherine (in role as Dr. Pazzarella) for the hand-shake as she was sitting at the back; my intent there was to infiltrate the participants' space, to provoke them into action. Such provocation is definitely picked up by Olga (video clip B):

1. TiR: You have to... find as much information as possible, and create an action plan. Is that clear? (Stands up, goes to the back and shakes Catherine's hand): Thank You!

2. Olga (confronting): Why always only...?

3. (General nervous laughter)

4. Olga: Only Pazzarella?

5. TiR: Dr. Pazzarella -

6. Olga: I have come, too!

7. (Sandra laughs nervously and turns around to the others)

8. TiR (provoking): Yes, You've come, but You always come... (hesitates) but... Dr. Pazzarella never comes... and she is much more important.

9. (Olga nods, subjugated)

10. TiR: We all know it, don't we? (Turns around to the others)

11. (Tense silence)

12. TiR (standing right in front of Olga): But look... (provoking) I don't know... if You really care... (holds her hand to shake it)

13. Olga: (nodding) Yes, thanks (firmly shake hands)

14. TiR: Thank You (challenging). So... why don't You draft the report for the action plan?

15. Olga (hesitating): Ehm yes.

16. TiR: Alright. I'm looking forward to i- 
17. Olga: Yes, I am... my heart is here, in this building... with... with You, Miss Colombo.

18. (General laughter)

19. TiR (flattered): Thanks! (Insecure, anxious) Will everything be OK?

20. Olga (reassuring, confident): I think it will.

[2.2.3:28:52] In this extract, we see Olga reclaiming her status over another participant (Catherine). We also see the subtle interplay of status and power between Olga and the teacher-in-role: in Turn 1, I hold the power by demanding an action plan; by Turn 19, I delegate my power to Olga, by anxiously asking if "Everything will be OK". During the interview that followed, Olga states:

[In process drama] you need to create the class yourself. Everything... like, it's all about your imagination and things you want to say, want to... show, and when you are going to a standard class we're just kind of following the rules. Here, you choose the direction yourself. (Olga, p.3: 14-18)

In this extract, Olga captures the essence of process drama as imagination and meaning-making, or "Choosing the direction yourself". In the two classroom transcripts above, the actual nature of the utterances is close to that of a real conversation, in terms of agency and autonomy (van Lier 2007). As for the quality of the language, Yoriko pinpoints this well in the interview:

1. Yoriko: When we had the meeting, this is a new experience for me because usually, first I think, if the teacher asks me something, I think a lot, I arrange [the thoughts] a bit in my head and speak.

2. Erika: Sure

3. Y: But during the meeting and... I couldn't think, it was like a live conversation!

4. E: Yes, improvisation; and... so you've learnt that... you can improvise?

5. Y: Ye- $[\ldots]$ it's not too difficult, because I live with Italians anyway.

6. E: That's right, so you're always improvising!

7. Y: Yes, so every day I'm training (laughs) in this

8. E: Exactly, well done!

9. Y: Yes

10. E: And so... but in class it didn't... it didn't happen very often? 
11. Y: Yes, it happened but... like, sure, different... this is like at home, in the street, very reality.

12. E: Yes; and what about in the classroom, it isn't like it is at home?

13. Y: Not really. Each - sometimes it is, like... we chat together, during the break. (Yoriko, p.3: 4-20)

In this extract, Yoriko is comparing the kind of language arising from the improvisation to language in the streets, at home or 'during a break' in her L2 lesson (Turn 13). She is describing a kind of TL which is not classroom-bound; in her own words, "very reality". 5 Yoriko's opening comment also sheds light on her inner cognitive mechanisms for speech production ("First I think: if the teacher asks me something, I think a lot... and then I speak") and how these are altered by improvisation, to produce a TL that is more spontaneous, what she defines as "a live conversation" (Turn 3). These comments resonate with the discussion above on process drama triggering willingness to communicate spontaneously in the TL.

Below is an extract of the interview with teacher-participant Alfonso, who was observing this session. Alfonso is an accredited teacher trainer, with ten years of experience. Commenting on this episode, Alfonso says:

The moment when... I think, from their point of view, it was most gratifying when they took on the role of ... the psychologist and... in that moment, there they were the real protagonists, because they had to interact for three, four minutes taking on a role... completely opposite to themselves, and so this made them feel... special; and they all participated with the same intensity. (Alfonso, p.12: 46)

It is precisely the nature of this 'intensity' that my research is concerned with; the kind of intensity, in terms of engagement, created by particular dramatic strategies rather than others. During the teacher-participant focus group VSR session, I showed videos of this episode and asked teachers to comment: all teachers-participants who had attended that workshop stated that, in that episode, Yoriko and Olga seemed particularly engaged on a communicative and affective level (TP FG, 12:55).

Indeed, cross-referencing these observations with the student-participant questionnaires, they confirm a high engagement in communicative and affective levels. [Insert table here] As the questionnaire data reports, both Yoriko and Olga indicate being highly engaged on a 'communicative' level, rating it at the highest score (10/10); both are slightly less, but still very engaged on an 'affective' level (9/10 and 8/10). Furthermore, the video recording of this episode indicate high engagement levels in terms of body language and physiological responses in the participants' behaviour. The visual data thus confirms high engagement levels on a communicative/affective domain.

\footnotetext{
5 Original text: "molto realtà".
} 
As for the intercultural level, both participants indicated to be moderately engaged (5/10). The discrepancy between participants' perceptions of their communicative/affective and intercultural engagement has generated further findings, connected with implicit/explicit intercultural tension in the drama, which are beyond the scope of this discussion (paper presented at the XI ACIS conference, University of Melbourne, July 2011).

Overall, by cross-referencing data sets it seems that these strategies impacted positively on students' willingness to communicate in the TL, and especially when the teacher-in-role was framed as teacher-artist, rather than teacher-asentertainer. By comparing the two transcripts above with the transcript in the previous section, a difference emerges in how a mutual understanding of the 'teacher-artist' stance differs to a 'teacher-entertainer', in terms of active engagement, dialogic interaction and agency.

\section{Conclusion}

In this paper, I introduced process drama pedagogy for teaching Additional Languages, focussing on two main strategies: teacher-in-role and mantle of the expert. These experiential strategies are innovative as they challenge the classroom power dynamics in terms of status, agency, and interaction. By reversing the role/status dynamics, they can be beneficial in stimulating confidence in the L2/AL speaker, lowering speakers' affective filters and creating a more spontaneous language.

I discussed the artistic collaboration involved between facilitator and participants, and the core principles of improvisation upon which it is based. I identified a difference between the 'teacher-entertainer' and 'teacher-artist', with the former resulting in a passive engagement, the latter producing an active engagement. I argued that, for this to occur, the improvisation requires the teacher-in-role to operate as a teacher-artist. However, the issue remains of how to design teacher training processes that can help language teachers to apprehend the aesthetic mode of process drama pedagogy, and the kinds of training experiences necessary to establish the flexibility required to operate as a teacher-artist in the language classroom. These, and other questions regarding $\mathrm{AL}$ process drama teacher education, are yet to be mapped out in future research.

\section{Bibliography}

Araki Metcalfe, Naoko (2008): Introducing Creative Language Learning In Japan Through Educational Drama. In: Drama Australia Journal (NJ) 31/2, 45-57

Araki Metcalfe, Naoko (2007): The Waterhole: Using Educational Drama As A Pedagogical Tool In A Foreign Language Class At A Public Primary School In Japan. University of Melbourne: Parkville 
Araki Metcalfe, Naoko (2001): Where Is Tora? Implementing Process Drama In Japanese Language Classes At An Australian Primary School. University of Melbourne: Parkville

Barab, Sasha; Squire, Kurt (2004): Design-Based Research: Putting A Stake In The Ground. In: The Journal of the Learning Sciences 13/1, 1-14

Belliveau, George; Bournot-Trites, Monique, Séror, Jeremie; Spiliotopoulos, Valia (2007): The Role Of Drama On Cultural Sensitivity, Motivation And Literacy In A Second Language Context. In: Journal for Learning through the Arts: a Research Journal on Arts Integration in Schools and Communities 3/1, 1-33

Bolton, Gavin (1979): Towards A Theory Of Drama In Education. London: Longman

Bowell, Pamela; Heap, Brian (2005): Drama On The Run: A Prelude To Mapping The Practice Of Process Drama. In: Journal of Aesthetic Education 39/4, 5-69

Bowell, Pamela; Heap, Brian (2001): Planning Process Drama. London: David Fulton

Bruner, Jerome S.; Jolly, Alison; Sylva, Kathy (eds.) (1976): Play: Its Role In Development And Evolution. New York: Penguin Books

Dewey, John (1934): Art As Experience. New York: Perigee

Dunn, Julie; Stinson, Madonna (2011): Not Without The Art!! The Importance Of Teacher Artistry When Applying Drama As Pedagogy For Additional Language Learning. In: Research in Drama Education: The Journal of Applied Theatre and Performance 16/4, 617-633

Eisner, Elliot W. (1985): The Educational Imagination: On The Design And Evaluation Of School Programs. New York: MacMillan

Ethell, Ruth G.; McMeniman, Marilyn M. (2000): Unlocking The Knowledge In Action Of Anexpert Practitioner. In: Journal of Teacher Education 51/2, 87-101

Heathcote, Dorothy; Bolton, Gavin (1995): Drama For Learning: Dorothy Heathcote's Mantle Of The Expert Approach To Education. Portsmouth: Heinemann

Heathcote, Dorothy (1973): Drama As Challenge. In: Lambert, Johnson; O'Neill, Cecily (eds.): Dorothy Heathcote, Collected Writings of Drama and Education. London: Hutchinson

Johnstone, Keith (1999): Impro For Storytellers. New York: Routledge Theatre Arts Books

Kao, Shin Mei; O'Neill, Cecily (1998): Words Into Worlds: Learning A Second Language Through Process Drama. London: Ablex Publishing Corporation

Lantolf, James P. (ed.) (2000): Sociocultural Theory And Second Language Learning. Oxford: Oxford University Press

Marshall, Catherine; Rossman, Gretchen (2006): Designing Qualitative Research. Thousands Oaks: Sage Publications 
McLaren, Peter (1986): Schooling As A Ritual Performance: Towards A Political Economy Of Educational Symbols And Gestures. London: Routledge and Kegan Paul

Neelands, Jonothan; Goode, Tony (2000): Structuring Drama Work: A Handbook Of Available Forms In Theatre And Drama. Cambridge: Cambridge University Press

O'Neill, Cecily (2006): Dialogue and Drama. In: Taylor and Christine D. Warner (eds.): Structure And Spontaneity: The process drama of Cecily O'Neill. Sterling, VA: Trentham

O’Neill, Cecily (1995): Drama Worlds: A Framework For Process Drama. Portsmouth: Heinemann

O’Toole, John; Dunn, Julie (2002): Pretending To Learn: Helping Children Learn Through Drama. French's Forest, N.S.W: Pearson Education

Owens, Allan; Barber, Keith (2005): Mapping Drama. Melbourne: Phoenix Education

Piazzoli, Erika (2010): Process Drama And Intercultural Language Learning: An Experience Of Contemporary Italy. In: Research in Drama Education: The Journal of Applied Theatre and Performance 15/3, 385-402

Piazzoli, Erika (2011a): Process Drama: The Use Of Affective Space To Reduce Language Anxiety In The Additional Language Learning Classroom. In: Research in Drama Education: The Journal of Applied Theatre and Performance 16/4, 557-573

Piazzoli, Erika (2011b): Film And Drama Aesthetics For Additional Language Teaching. In: Winston, Joe (ed.): Second Language Learning Through Drama: Practical Techniques And Applications. London: Routledge

Platt, Elisabeth; Brooks, Frank (2002): Task Engagement: A Turning Point In Foreign Language Development. In: Language Learning 52/2, 365-400

Rothwell, Julia (2011): Drama And Languages Education: Authentic Assessment Through Process Drama. In: Winston, Joe (ed.): Second Language Learning Through Drama: Practical Techniques And Applications. London: Routledge

Schewe, Manfred L. (2002): Tapping The Students' Bodily-Kinesthetic Intelligence. In: Bräuer, Gerd (ed.): Body And Language: Intercultural Learning Through Drama. Westport: Ablex Publishing

Schön, Donald (1983): The Reflective Practitioner: How Professionals Think In Action. London: Temple Smith

Stinson, Madonna (2008): Process Drama And Teaching English To Speakers Of Other Languages. In: Manuel, Jacqueline; Hughes, John; Anderson, Michael (eds.): Drama and English teaching: Imagination, action and engagement. Oxford : Oxford University Press

Stinson, Madonna (2009): Drama Is Like Reversing Everything: Intervention Research As Teacher Professional Development. In: Research in Drama Education 14/2, 225-243 
Stinson, Madonna; Winston, Joe (2011): Drama Education And Second Language Learning: A Growing Field Of Practice And Research. In: Research in Drama Education: The Journal of Applied Theatre and Performance 16/4, 479-488

Stinson, Madonna; Freebody, Kelly (2006): The DOL Project: An Investigation Into The Contribution Of Process Drama To Improved Results In English Oral Communication. In: Youth Theatre Journal 20, 27-41.

Taylor, Philip; Warner, Christine (2006): Structure And Spontaneity: The Process Drama Of Cecily O'Neill. Sterling, VA: Trentham

Van Lier, Leo (2007): Action-Based Teaching, Autonomy And Identity. In: Innovation in Language Teaching and Learning 1/1, 46-65

Van Lier, Leo (1996): Interaction In The Language Curriculum: Awareness, Autonomy, And Authenticity. London: Longman

Vygostky, Lev (1978): Mind In Society: The Development Of Higher Psychological Processes. Cambridge, MA: Harvard University Press

Winston, Joe (ed.) (2011): Second Language Learning Through Drama: Practical Techniques And Applications. Padstow, Cornwall: Routledge

Yaman Ntelioglu, Burcu (2011): 'But Why Do I Have To Take This Class?' The Mandatory Drama-ESL Class And Multiliteracies Pedagogy. In: Research in Drama Education 16/4, 595-615 


\section{Appendix}

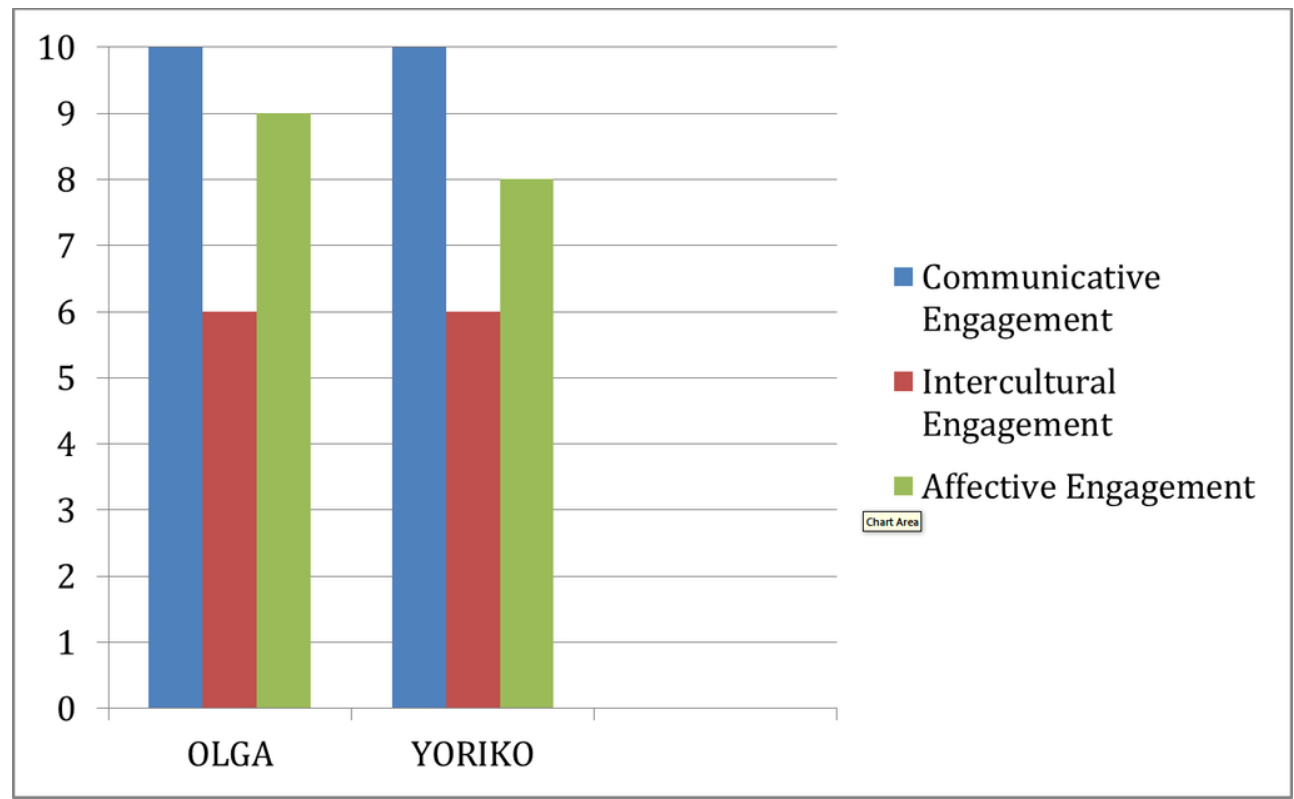

Figure 2: Student-participant self-scores of engagement levels (after workshop 2, 'teacher in role' episode). 